\title{
Corrigendum: T-cell activation is an immune correlate of risk in BCG vaccinated infants
}

Helen A. Fletcher, Margaret A. Snowden, Bernard Landry, Wasima Rida, Iman Satti, Stephanie A. Harris, Magali Matsumiya, Rachel Tanner, Matthew K. O'Shea, Veerabadran Dheenadhayalan, Leah Bogardus, Lisa Stockdale, Leanne Marsay, Agnieszka Chomka, Rachel Harrington-Kandt, Zita-Rose Manjaly-Thomas, Vivek Naranbhai, Elena Stylianou, Fatoumatta Darboe, Adam Penn-Nicholson, Elisa Nemes, Mark Hatherill, Gregory Hussey, Hassan Mahomed, Michele Tameris, J. Bruce McClain, Thomas G. Evans, Willem A. Hanekom, Thomas J. Scriba \& Helen McShane

Nature Communications 7:11290 doi: 10.1038/ncomms11290(2016); Published 12 Apr 2016; Updated 6 May 2016

The original version of this Article contained an error in the spelling of the author Mark Hatherill, which was incorrectly given as Mark Hatheril. This has now been corrected in both the PDF and HTML versions of the Article.

This work is licensed under a Creative Commons Attribution 4.0 International License. The images or other third party material in this article are included in the article's Creative Commons license, unless indicated otherwise in the credit line; if the material is not included under the Creative Commons license, users will need to obtain permission from the license holder to reproduce the material. To view a copy of this license, visit http://creativecommons.org/licenses/by/4.0/ 